\title{
Synthesis and Characterization of Nano Structured Pd-Ni and Pd-Ni-C Composites Towards Electrooxidation of Alcohols
}

\author{
R. Awasthi, Anindita and R.N. Singh* \\ Department of Chemistry, Faculty of Science, Banaras Hindu University, Varanasi-221005, India
}

\begin{abstract}
Nanostructured (100-x)\% Pd -x \% Ni (x = 1, 2, 5, 10, and 20) and $(90-y) \% \mathrm{Pd}-10 \% \mathrm{Ni}-\mathrm{y} \% \mathrm{C}(\mathrm{y}=0.5,1,2,5$, and 10) composite films are obtained on glassy carbon electrodes and characterized by XRD, TEM, cyclic voltammetry and chronoamperometric techniques for use as electrocatalysts towards methanol, ethanol, ethylene glycol and glycerol oxidations in $1 \mathrm{M} \mathrm{KOH}$ at $25^{\circ} \mathrm{C}$. Results show that addition of $\mathrm{Ni}$ from 1 to $20 \%$ to the pure Pd electrode increases the electrocatalytic activity for electrooxidation of each alcohol showing maximum with $10 \% \mathrm{Ni}$. Further, all the Pd-Ni composite electrodes exhibit better electrocatalytic performance in the case of ethanol electrooxidation. The rate of electrooxidation of different alcohols on the active $90 \% \mathrm{Pd}-10 \% \mathrm{Ni}$ electrode at $\mathrm{E}=-0.20 \mathrm{~V}$ in $1 \mathrm{M} \mathrm{KOH}$ is observed to follow the order: ethanol $>$ methanol $>$ ethylene glycol $>$ glycerol. Incorporation of $\mathrm{C}$ from 0.5 to $10 \%$ to the active Pd$10 \% \mathrm{Ni}$ composite improves the electrocatalytic performance of the electrode further, the magnitude of improvement being greatest with $5 \% \mathrm{C}$. The apparent electrocatalytic activity of the active $90 \% \mathrm{Pd}-10 \% \mathrm{Ni}$ electrode at $\mathrm{E}=-0.20 \mathrm{~V}$ is enhanced $\sim 1.3$ to 2.1 times with introduction of $5 \% \mathrm{C}$.
\end{abstract}

Keywords: Nanocomposites, electrooxidation, alcohols, direct alcohol fuel cells.

\section{INTRODUCTION}

Pt-based metals and alloys are the most active anode materials [1-4] for oxidation of alcohols, particularly methanol and ethanol in acid direct alcohol fuel cells (DAFCs). However, they are pretty costly and undergo deactivation by intermediates/products, particularly $\mathrm{CO}$ formed during the oxidation [5].

It is therefore desired to develop new electrode materials for DAFC anodes that do not contain Pt or contain tiny amounts of this material and are able to oxidize primary and secondary alcohols with fast kinetics and have tolerable deactivation. In this context, $\mathrm{Pd}$ is the most attractive replacement for Pt. It is because of the fact that as compared to $\mathrm{Pt}, \mathrm{Pd}$ is low cost and abundant in nature [6]. More importantly, unlike Pt-based metals and alloys, Pd-based electrocatalysts can be highly active for the oxidation of a large variety of substrates in alkaline environment [7-9]. In the latter environment, a number of non-noble metals are also sufficiently stable which can be introduced to Pd to enhance its catalytic efficiency as well as poisoning tolerance in alcohol oxidation.

In recent years, efforts have been made to improve the catalytic efficiency of Pd catalysts by suitable means [1031]. Shen and coworkers obtained nanostructured Pd catalyst on a number of supports, namely Vulcan XC-72 [10], MWCNTs (multiwalled carbon nanotubes) [10], ACFs (active carbon fibers) [10], CMSs (carbon microspheres) [11] and HCSs (hollow carbon spheres) [12] using $\mathrm{PdCl}_{2}$ as metal precursor and formic acid and tannic acid as reducing agents and determined their activities towards ethanol

*Address correspondence to this author at the Department of Chemistry, Faculty of Science, Banaras Hindu University, Varanasi-221005, India; Tel: 0542-6701596; Fax: 91-542-2368127; E-mail: rnsbhu@rediffmail.com oxidation by cyclic voltammetry and chronoamperometry under comparable experimental conditions in alkaline medium. The $\mathrm{Pd} / \mathrm{MWCNT}$ catalyst indicated better activity than $\mathrm{Pd} / \mathrm{ACF}$ or $\mathrm{Pd} / \mathrm{C}$ electrode. The smaller size and higher dispersion of Pd nanoparticles on the Pd/MWCNT surface have been considered as the key factors accounting for the higher catalytic activity. Bambagioni et al. [13] have studied the performance of $\mathrm{Pd} / \mathrm{MWCNT}$ for the oxidation of methanol, ethanol, and glycerol in $2 \mathrm{M} \mathrm{KOH}$. The results exhibited high activity of the catalyst for the oxidation reactions of all alcohols even at metal loadings as low as 17 $20 \mu \mathrm{g} \mathrm{cm}^{-2}$. Shen and $\mathrm{Xu}$ have demonstrated that the electroless reduction of $\mathrm{PdCl}_{2}$ adsorbed onto oxide/C materials (oxide $=\mathrm{CeO}_{2}, \mathrm{Co}_{3} \mathrm{O}_{4}, \mathrm{Mn}_{3} \mathrm{O}_{4}, \mathrm{NiO}$ ) produces a much higher electrochemical stability vis-a-vis the electrocatalytic effect for alcohol oxidations than any $\mathrm{Pd} / \mathrm{C}$ or $\mathrm{Pt} / \mathrm{C}$ under comparable experimental conditions [7-9, 14]. Out of all electrocatalyts investigated, $\mathrm{Pd}_{-}-\mathrm{Co}_{3} \mathrm{O}_{4} \quad(2: 1$, $\mathrm{w}: \mathrm{w}) / \mathrm{C}$ shows the highest activity for the electrooxidation of methanol, ethylene glycol, and glycerol, while the most active catalyst for the ethanol oxidation was $\mathrm{Pd}-\mathrm{NiO}$ $(6: 1, w: w) / C$. Chu et al. [15] found that a composite electrode of $\mathrm{Pd}$ and $\mathrm{In}_{2} \mathrm{O}_{3}$ with a mass ratio of 10:3 was twice as much more active than $\mathrm{Pd} / \mathrm{MWCNT}$. Wang et al. [16, 17] discovered that the electrocatalytic activity of Pd nanowire arrays (NWA) electrode is much more active for the electrooxidation reaction of ethanol than either a Pd film or a $\mathrm{PtRu} / \mathrm{C}$ catalyst. Zhang et al. [18] obtained well dispersed $\mathrm{Pd}$ nanoparticles on the surface of vanadium oxide nanotubes $\left(\mathrm{VO}_{\mathrm{x}}\right.$-NTs) through a simple reductive process and investigated them as electrocatalysts for MOR in alkaline medium. The new materials were found to exhibit an excellent electrocatalytic activity and good stability under alkaline condition. Li et al. $[18,19]$ obtained $\mathrm{Pd}$ nanoparticles supported on either $\beta-\mathrm{MnO}_{2}$ nanotubes or VOx nanotubes and reported that the methanol 
electrooxidation on both the catalysts in $\mathrm{NaOH}$ solution was better than traditional $\mathrm{Pd} / \mathrm{C}$ catalyst at comparable metal loadings.

Bagchi and Bhattacharya [20] synthesized PdRu/Ni catalysts and used to study the ethanol electrooxidation in alkaline solutions. Bambagioni et al. [21] investigated the ethanol oxidation reaction on the catalysts $\mathrm{Pd}-(\mathrm{Ni}-\mathrm{Zn}) / \mathrm{C}$ and $\mathrm{Pd}-(\mathrm{Ni}-\mathrm{Zn}-\mathrm{P}) / \mathrm{C}$. They observed specific current densities which were higher than $3600 \mathrm{~A} \mathrm{~g}^{-1} \mathrm{Pd}$. In addition, these electrodes exhibited an excellent stability for the oxidation of ethanol in alkaline medium.

Several alloys with other metals were also obtained and investigated as electrocatalysts for alcohol oxidation. Active $\mathrm{Pd}$ alloys for alcohol oxidation were Pd-Pt [22-24], PdAu [25-27] and PdNi [28, 29]. In particular, Xu et al. [27] have observed that the addition of $\mathrm{Au}$ to $\mathrm{Pd} / \mathrm{C}$ significantly promotes the catalytic activity for the electroxidation of 2propanol and also increases its stability.

Very recently, Singh et al. [5, 28, 30, 31] synthesized nanostructured $\mathrm{Pd}-\mathrm{x} \mathrm{wt}^{\mathrm{O}} \mathrm{C}(\mathrm{x}=0.5,1,2$ and 5) and $\mathrm{Pd}-\mathrm{y}$ $\mathrm{wt} \%$ MWCNT ( $\mathrm{y}=1,2$ and 5 ) by borohydride reduction method and investigated for electrocatalysis of methanol [30, $31]$ and ethanol $[5,28]$ oxidation reactions in $1 \mathrm{M} \mathrm{KOH}$ at $25^{\circ} \mathrm{C}$. The Pd- 1 wt $\%$ MWCNT and $\mathrm{Pd}-0.5 \mathrm{wt} \% \mathrm{C}$ electrodes exhibited the highest catalytic efficiencies for oxidation of ethanol. It was further noted that $1-2 \mathrm{wt} \% \mathrm{Ni}$ additions to Pd$1 \mathrm{wt} \%$ MWCNT enhanced the electrocatalytic activity of the electrode for ethanol oxidation. In contrast, 0.5 to $2 \mathrm{wt} \% \mathrm{Ni}$ additions to the active $\mathrm{Pd}-0.5 \mathrm{wt} \% \mathrm{C}$ composite indicated somewhat adverse effect on electrocatalytic activity. Thus, the role of $\mathrm{Ni}$ in the complex composite catalyst used for electrocatalysis of alcohols in alkaline medium is not very clear. It was therefore planned to prepare binary nanocomposites of $\mathrm{Pd}$ and $\mathrm{Ni}$ of varied compositions with aimed at to optimize the percentage of $\mathrm{Ni}$ in the composite for producing the highest electrocatalytic effect and then increase its electrocatalytic activity further through addition of varying amounts of nanocarbon. Results of the investigation are presented in this paper.

\section{EXPERIMENTAL}

\subsection{Electrocatalyst Preparation}

Before use, the carbon nanopowder (Aldrich, 99+ \%, particle size $\leq 30 \mathrm{~nm}$, BET surface area $>100 \mathrm{~m}^{2} \mathrm{~g}^{-1}$, Pr. No. 7440-44-0) was activated by refluxing in concentrated $\mathrm{HNO}_{3}$ for $5 \mathrm{~h}$ as described elsewhere [32]. $20 \mathrm{mg}$ of each $\mathrm{Pd}-\mathrm{Ni}$ composites containing 1, 2, 5, 10, and $20 \% \mathrm{Ni}$ were prepared. For the purpose, the required amount (0.0329$0.02668 \mathrm{~g}$ ) of $\mathrm{PdCl}_{2}$ (anhydrous: Merck, Pr. No. 61777900011730 ) in $2 \mathrm{ml}$ acidified distilled water was dissolved and to this added the required amount (0.01619$0.00088 \mathrm{~g}$ ) of $\mathrm{NiCl}_{2} \cdot 6 \mathrm{H}_{2} \mathrm{O}$ (Merck, Pr. No. 61761305001730 ) and stirred the solution well. In order to carry out the complete reduction of the metal ions, the $\mathrm{NaBH}_{4}$ (Sigma - Aldrich, Pr. No.452874) solution was added in slightly excess under vigorous stirred condition. The addition of $\mathrm{NaBH}_{4}$ solution was made in a drop-wise manner. Similarly, ternary composites of $\mathrm{Pd}, \mathrm{C}$ and Ni were also prepared. The amount of $\mathrm{C}$ used ranged between 0.0001 and $0.0020 \mathrm{~g}$. Each catalyst formed as a solid residue in the solution was centrifuged, repeatedly washed with double distilled water so as to remove $\mathrm{Cl}^{-}$ions and finally dried over night in a vacuum oven. The percent compositions of each element in the composite shown in the text are by weight.

\subsection{Electrode Preparation}

The catalyst was dispersed in a ternary mixture of double distilled water, isopropanol and ethanol $(1: 1: 2)$ and then ultrasonicated for $15 \mathrm{~min}$. so as to obtain an ink. To obtain the electrode, 2-3 drops of ink were dropped on to a pretreated glassy carbon (GC) plate through a syringe, dried and then one drop of 1\% Nafion solution (Alfa Aesar) was dropped over the dried catalyst layer to cover it. The catalyst electrodes, thus obtained, were finally irradiated with microwave ( $800 \mathrm{watt}$ ) for one minute. Prior to use as support for the catalyst, GC plates were first polished well on a micro cloth pad on a polishing machine with alumina powder and then dipped in $0.2 \mathrm{M} \mathrm{H}_{3} \mathrm{PO}_{4}$ solution for $5 \mathrm{~min}$, degreased in acetone by ultrasonication, washed with distilled water and dried. Electrical contact with the catalyst overlayer and electrode mounting were carried out as described elsewhere [33].

\subsection{Material Characterization}

X-ray diffraction (XRD) patterns of composite films on GC were recorded on an X-ray diffractometer (Thermo Electron) using $\mathrm{CuK} \alpha$ as the radiation source $(\lambda=1.541841$ $\AA)$. Morphology of the catalytic films has been studied by a transmission electron microscope (TECNAI G ${ }^{2}$ FEI). To obtain TEM pictures, the catalyst was dispersed in methanol and a drop of this suspension was placed onto a carbon coated copper grid, and dried.

\subsection{Electrochemical Studies}

Electrochemical studies, namely, cyclic voltammetry and chronoamperometry have been carried out in a threeelectrode single-compartment Pyrex glass cell using a potentiostat/galvanostat Model 273A (PARC, USA). A Ptfoil $\left(\sim 8 \mathrm{~cm}^{2}\right)$ and an $\mathrm{Hg} / \mathrm{HgO} / 1 \mathrm{M} \mathrm{KOH}$ were used as auxiliary and reference electrodes, respectively. Cyclic voltammetry $(\mathrm{CV})$ of each electrocatalyst has been carried out between -0.80 and $+0.70 \mathrm{~V}$ versus $\mathrm{Hg} / \mathrm{HgO}$ in $1 \mathrm{M} \mathrm{KOH}$ with and without containing alcohols at $25^{\circ} \mathrm{C}$. Before recording the final voltammogram each electrode was cycled for five runs at a scan rate of $50 \mathrm{mV} \mathrm{s}^{-1}$ in $1 \mathrm{M} \mathrm{KOH}$. All electrochemical experiments were performed in an $\mathrm{Ar}$ deoxygenated $1 \mathrm{M} \mathrm{KOH}$ (GR Merck, 85\%) + $1 \mathrm{M}$ alcohol (methanol, ethanol, glycerol, ethylene glycol) at $25^{\circ} \mathrm{C}$. The potential values mentioned in the text are given against the $\mathrm{Hg} / \mathrm{HgO} / 1 \mathrm{M} \mathrm{KOH}$ electrode only. The electrochemical activity data given in the text and Tables are average ones and have been obtained by recording CV curves on three electrodes of each composite catalyst under identical experimental conditions.

\section{RESULTS AND DISCUSSION}

\subsection{XRD/TEM}

The XRD patterns of $99 \% \mathrm{Pd}-1 \% \mathrm{Ni}, 90 \% \mathrm{Pd}-10 \% \mathrm{Ni}$, $89 \% \mathrm{Pd}-10 \% \mathrm{Ni}-1 \% \mathrm{C}, 85 \% \mathrm{Pd}-10 \% \mathrm{Ni}-5 \% \mathrm{C}$ and $80 \% \mathrm{Pd}-$ $10 \% \mathrm{Ni}-10 \% \mathrm{C}$ composite films as deposited on GC are shown in Fig. (1). Features of all the diffractograms displayed in Fig. (1) indicate that the composite materials are 
in either amorphous phase or have very small particle sizes. Further, it is observed that all the diffractograms excepting for $80 \% \mathrm{Pd}-10 \% \mathrm{Ni}-10 \% \mathrm{C}$ display the three characteristic peaks for the face centered cubic (fcc) structure of Pd. These peaks are found at $2 \theta=\sim 40^{\circ}(\mathrm{d}=2.25 \AA), 46.5^{\circ}(\mathrm{d}=1.95$ $\AA)$ and $68.2^{\circ}(\mathrm{d}=1.37 \AA)$ and can be assigned to (111), (200), and (220) planes, respectively. The reported d-value for the strongest $(100 \%)$ peak of pure Pd is $2.246 \AA$ (JCPDS-05$0681)$. The most intense peak of pure Ni corresponding to dvalue, $2.0340 \AA$ (JCPDS-04-0850) has not been observed in $\mathrm{XRD}$ patterns. This indicates that $\mathrm{Ni}$ in elemental form is absent. The observation of Fig. (1) further shows that $\mathrm{Ni}$ addition increases the $\mathrm{d}$-value for the $100 \%$ peak of pure $\mathrm{Pd}$ by $\sim 0.02 \AA$, the magnitude of increment, however, being the greatest with $1 \% \mathrm{Ni}$. The slight increase in the Pd lattice parameter in presence of $\mathrm{Ni}$ can be ascribed to the formation of a solid solution of $\mathrm{Ni}$ in $\mathrm{Pd}$ [34]. The peaks observed at $2 \theta$ $=26^{\circ}(\mathrm{d}=3.42 \AA)$ and $2 \theta=43.2^{\circ}(\mathrm{d}=2.08 \AA)$ correspond to the (002) plane of GC (JCPDS-23-0064) and (012) plane of $\mathrm{NiO}$ (JCPDS-44-1159), respectively. It may be noted that addition of $\mathrm{C}$ in $90 \% \mathrm{Pd}-10 \% \mathrm{Ni}$ alloy changes the XRD significantly. The peak corresponding to $\mathrm{Pd}$ (111) plane becomes broader and of relatively lower intensity with increase of $\mathrm{C}$ addition. This may be attributed to the reduction of the particle size of $\mathrm{Pd}$. On the other hand, the peak corresponding to $\mathrm{NiO}(012)$ becomes relatively more pronounced with $10 \% \mathrm{C}$ addition. Probably, the volume fraction of $\mathrm{NiO}(012)$ has increased due to addition of carbon. The Pd (111) diffraction peak was used to calculate the crystallite size according to Scherrer formula and values, so estimated, ranged between 7 and $11 \mathrm{~nm}$.

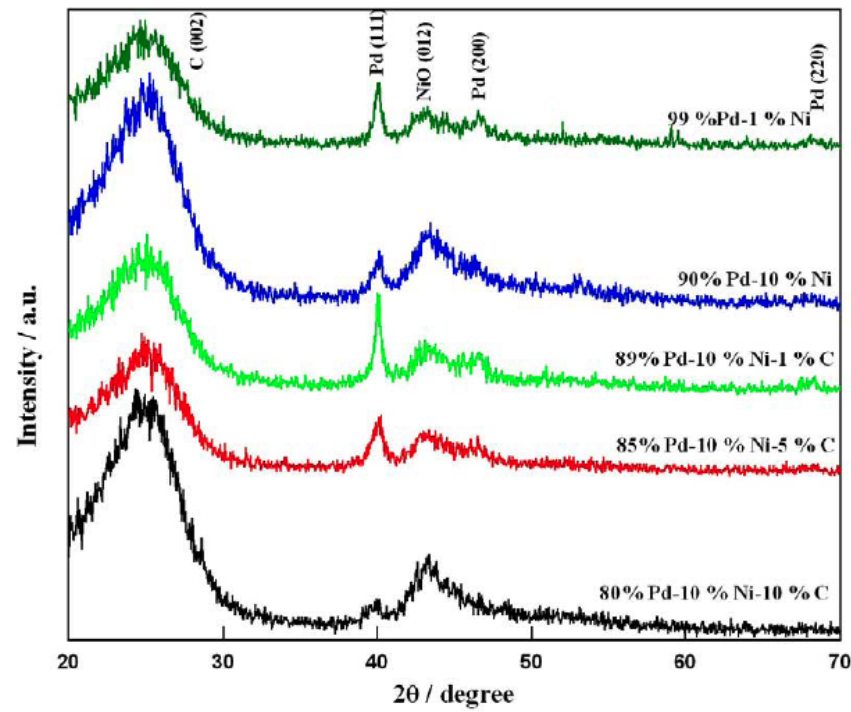

Fig. (1). The XRD patterns of 99\%Pd-1 \% Ni, 90\%Pd-10\% Ni, $89 \% \mathrm{Pd}-10 \% \mathrm{Ni}-1 \% \mathrm{C}, 85 \% \mathrm{Pd}-10 \% \mathrm{Ni}-5 \% \mathrm{C}$ and $80 \% \mathrm{Pd}-10 \% \mathrm{Ni}-$ $10 \% \mathrm{C}$ composite films as deposited on GC.

The TEM pictures of only two catalysts, $90 \% \mathrm{Pd}-10 \% \mathrm{Ni}$ and $89 \% \mathrm{Pd}-10 \% \mathrm{Ni}-1 \% \mathrm{C}$ were taken and are reproduced in Fig. (2). This figure shows that composite particles are interlinked with each other producing a porous network. Further, $1 \% \mathrm{C}$ addition does not seem to change the surface morphology of the base $(90 \% \mathrm{Pd}-10 \% \mathrm{Ni})$ composite practically. Particles are nearly spherical and their sizes are in the same order $(\sim 7$ and $\sim 10 \mathrm{~nm}$ for $90 \% \mathrm{Pd}-10 \% \mathrm{Ni}$ and $89 \% \mathrm{Pd}-10 \% \mathrm{Ni}-1 \% \mathrm{C}$ respectively) as found by the XRD.

On selected area the electron diffraction patterns (Fig. 2e, g) of the catalysts show that the composite materials are crystalline and consist of mainly single phase

\subsection{Cyclic Voltammetry (CV)}

\subsubsection{Oxidation of Alcohols (Methanol, Ethanol, Glycerol, Ethylene Glycol) on Binary Composites of Pd and Ni}

The CV study of composite electrodes has been carried out at the scan rate of $50 \mathrm{mV} \mathrm{s}^{-1}$ in $1 \mathrm{M} \mathrm{KOH}+1 \mathrm{M}$ alcohol. The potential region, from $-0.80 \mathrm{~V}$ to $+0.70 \mathrm{~V}$ vs $\mathrm{Hg} / \mathrm{HgO}$, was employed to record $\mathrm{CV}$ curves. For the purpose of comparison, the cyclic voltammogram of each composite electrode in $1 \mathrm{M} \mathrm{KOH}$ without containing alcohol was also recorded. Features of $\mathrm{CV}$ curves for composite electrodes in $1 \mathrm{M} \mathrm{KOH}$ (without containing any alcohol) were similar. A typical voltammogram for $90 \% \mathrm{Pd}-10 \% \mathrm{Ni}$ electrode in $1 \mathrm{M}$ $\mathrm{KOH}$ is shown in Fig. (3).

Fig. (4a-d) represents cyclic voltammograms for the composite electrodes determined at $50 \mathrm{mV} \mathrm{s}^{-1}$ in $1 \mathrm{M} \mathrm{KOH}$ containing $1 \mathrm{M}$ alcohol (methanol/ethanol/ glycerol/ethylene glycol). The comparison of CVs of the composite electrodes recorded in the blank solution (1 M KOH) with those obtained in $1 \mathrm{M} \mathrm{KOH}+1 \mathrm{M}$ alcohol clearly demonstrates significant oxidation of each alcohol as indicated by two well defined anodic peaks, one observed on the forward and the other one, on the reverse scan. The observed anodic peak in the forward scan is due to the oxidation of freshly chemisorbed species derived from adsorption of alcohol molecule [5]. The observed anodic peak on reverse scan is primarily associated with removal of carbonaceous species which are not completely oxidized in the forward scan [35, 36]. The height of the anodic (oxidation) peak on the forward scan is considered as the measure of the electrocatalytic activity of the electrocatalysts used for the oxidation of alcohol in $1 \mathrm{M} \mathrm{KOH}$. Each $\mathrm{CV}$ curve was analyzed for the onset potential $\left(\mathrm{E}_{\mathrm{op}}\right)$ and the peak current $\left(I_{p}\right)$ and the corresponding peak potential $\left(E_{p}\right)$ for the forward scan and values, so obtained, are listed in Table 1. For clarity of data representation, the $\mathrm{E}_{\mathrm{op}}$ values are not shown in table.

Fig. (4) and Table 1 show that introduction of $\mathrm{Ni}$ from 1 to $10 \%$ to $\mathrm{Pd}$ increases the oxidation current in case of each alcohol, $1 \% \mathrm{Ni}$ addition being an exception. The presence of a higher percentage of $\mathrm{Ni}(20 \%)$ in the composite is found to have the adverse effect on electrocatalysis. It is noteworthy that all the $\mathrm{Pd}-\mathrm{Ni}$ composites prepared in the study have shown better performance in the case of electrooxidation of ethanol.

As in the cyclic voltammetry, the peak potential for oxidation of a particular alcohol varies with the nature of electrocatalyst, the electrocatalytic activities of $\mathrm{Pd}-\mathrm{Ni}$ composite electrodes have been compared at a common and constant potential $(\mathrm{E}=-0.20 \mathrm{~V})$, chosen prior to the alcohol oxidation peak current on the forward scan. At this potential the current produced due to oxidation of each alcohol on different composite electrodes was determined from Fig. (4) and displayed as a function of composition of $\mathrm{Ni}$ in the 


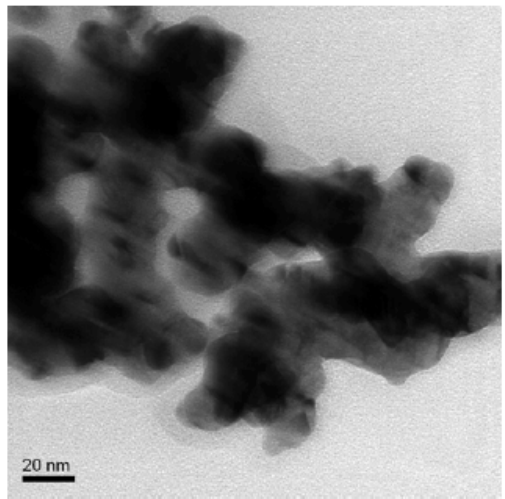

(a)

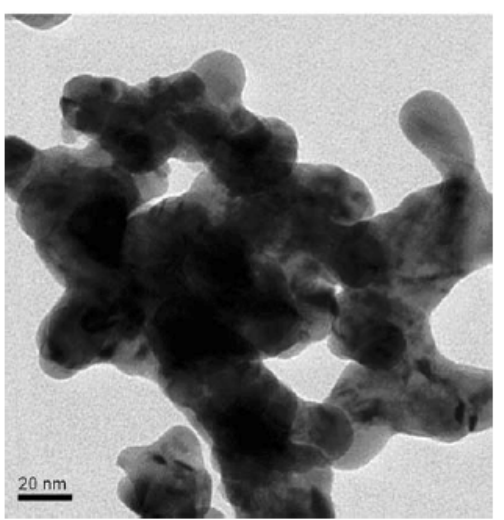

(c)

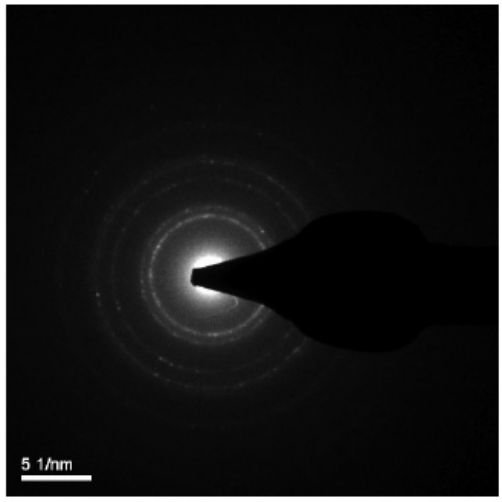

(e)

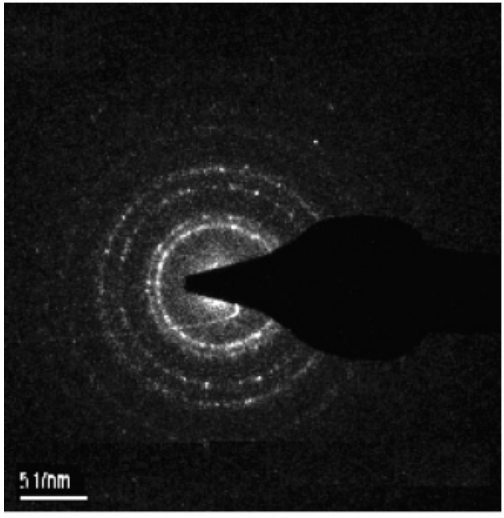

(g)

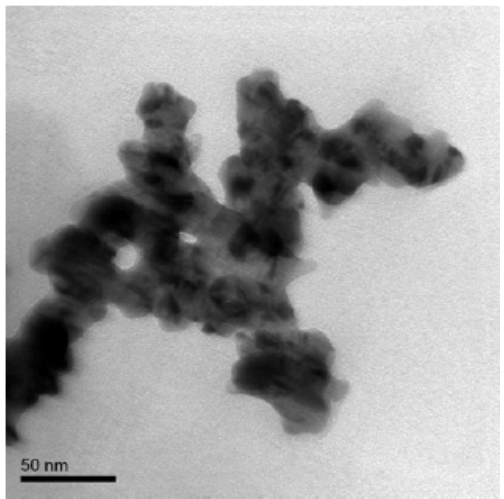

(b)

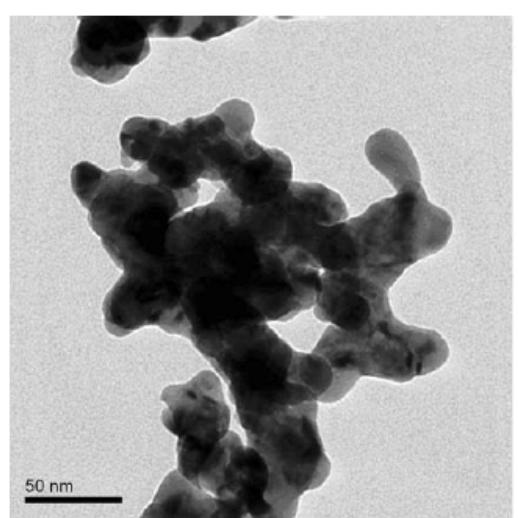

(d)

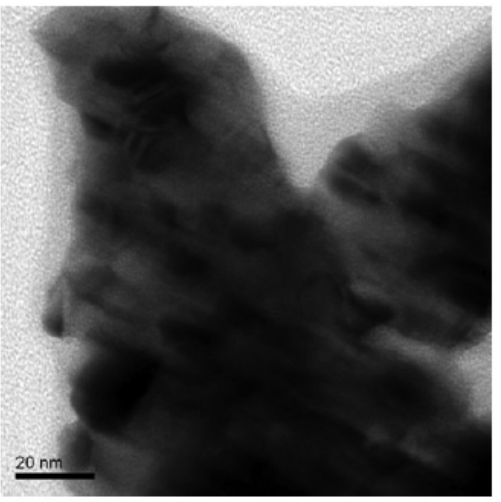

(f)

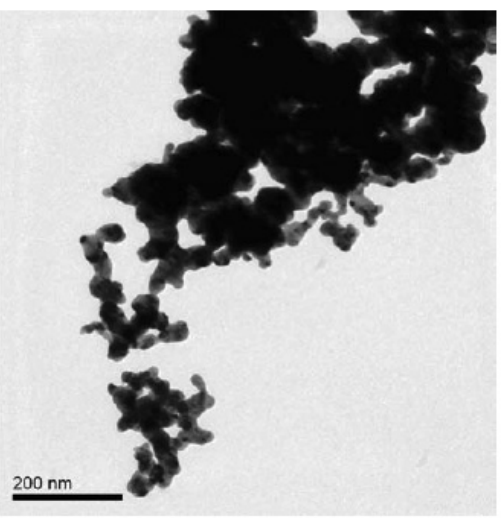

(h)

Fig. (2). TEM pictures of $90 \% \mathrm{Pd}-10 \% \mathrm{Ni}(\mathbf{a}, \mathbf{b}, \mathbf{e}$ and $\mathbf{f})$ and $89 \% \mathrm{Pd}-1 \% \mathrm{C}-10 \% \mathrm{Ni}(\mathbf{c}, \mathbf{d}, \mathbf{g}$ and $\mathbf{h})$ catalysts. 


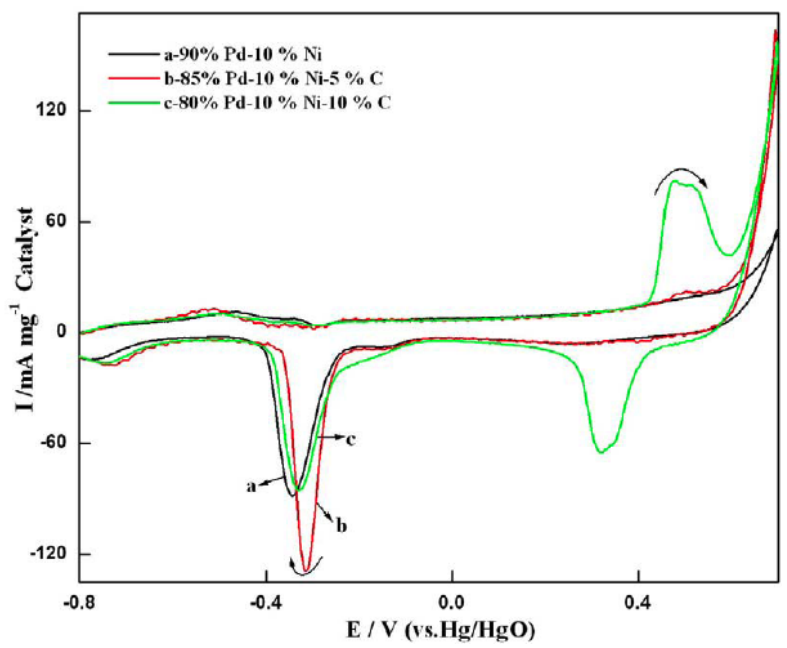

Fig. (3). Voltammograms for $90 \% \mathrm{Pd}-10 \% \mathrm{Ni}, 85 \% \mathrm{Pd}-10 \% \mathrm{Ni}-5 \%$ $\mathrm{C}$ and $80 \% \mathrm{Pd}-10 \% \mathrm{Ni}-10 \% \mathrm{C}$ electrode in $1 \mathrm{M} \mathrm{KOH}$ at scan rate of $50 \mathrm{mV} \mathrm{s}^{-1}$.

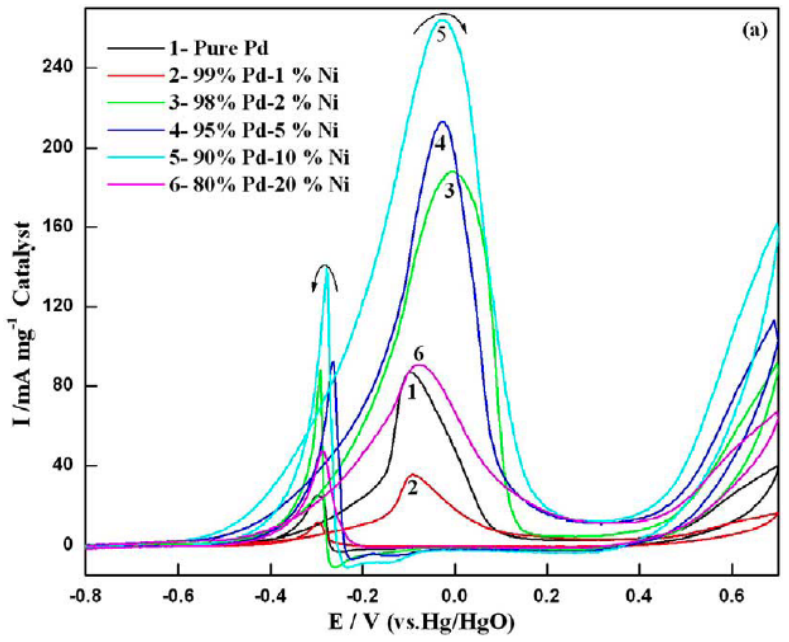

Fig. (4a). Voltammograms for $(100-x) \% P d-x \% N i(x=0,1,2,5$, 10 and 20) electrodes in $1 \mathrm{M} \mathrm{KOH}+1 \mathrm{M} \mathrm{CH}_{3} \mathrm{OH}$ at scan rate of 50 $\mathrm{mV} \mathrm{s}^{-1}$.

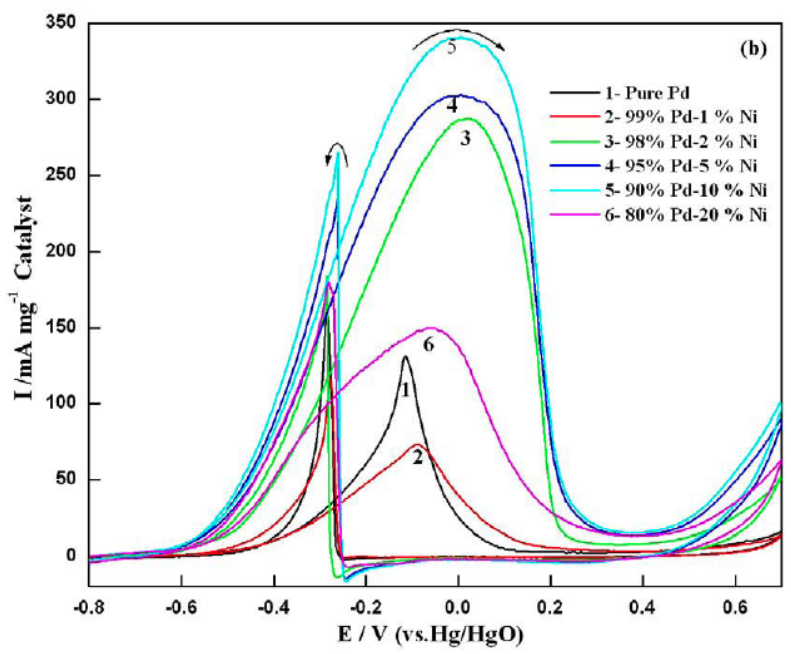

Fig. (4b). Voltammograms for $(100-\mathrm{x}) \% \mathrm{Pd}-\mathrm{x} \% \mathrm{Ni}(\mathrm{x}=0,1,2,5$, 10 and 20) electrodes in $1 \mathrm{M} \mathrm{KOH}+1 \mathrm{M} \mathrm{C}_{2} \mathrm{H}_{5} \mathrm{OH}$ at scan rate of $50 \mathrm{mV} \mathrm{s}^{-1}$.

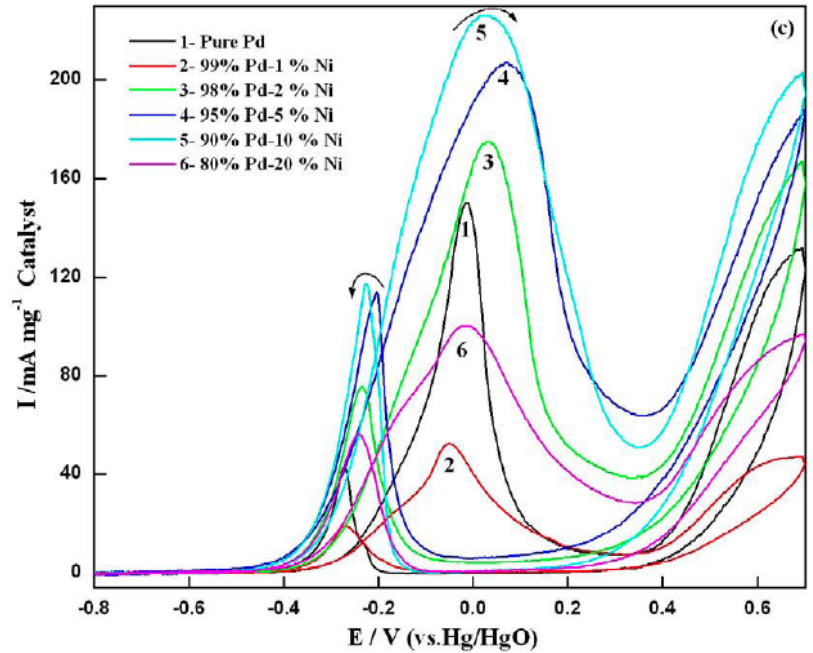

Fig. (4c). Voltammograms for $(100-\mathrm{x}) \% \mathrm{Pd}-\mathrm{x} \% \mathrm{Ni}(\mathrm{x}=0,1,2,5$, 10 and 20) electrode in $1 \mathrm{M} \mathrm{KOH}+1 \mathrm{M}$ Glycerol at scan rate of 50 $\mathrm{mV} \mathrm{s}^{-1}$.

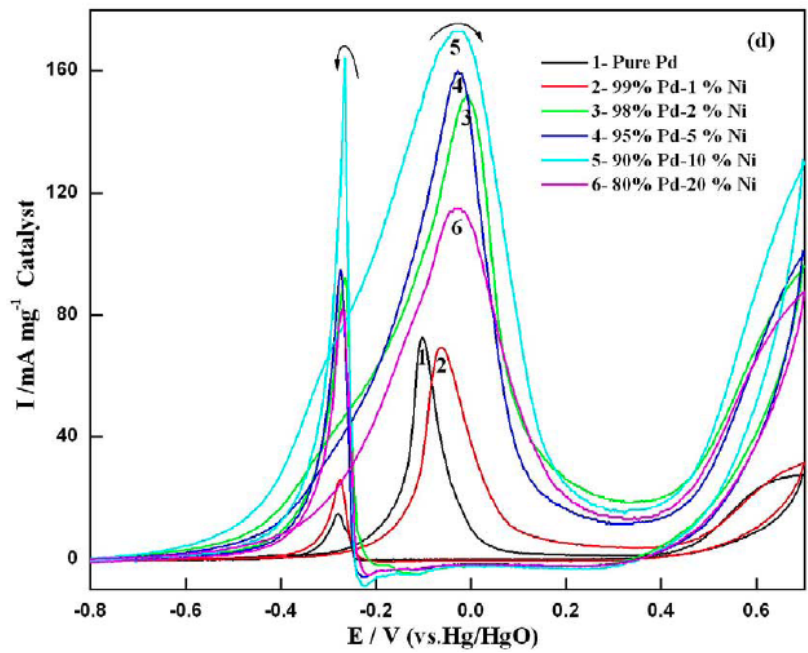

Fig. (4d). Voltammograms for $(100-x) \% P d-x \% ~ N i(x=0,1,2,5$, 10 and 20) electrode in $1 \mathrm{M} \mathrm{KOH}+1 \mathrm{M}$ Ethylene Glycol at scan rate of $50 \mathrm{mV} \mathrm{s}^{-1}$.

catalyst as shown in Fig. (5). This figure clearly demonstrates that the rates of oxidation of alcohols are higher at the $90 \% \mathrm{Pd}-10 \% \mathrm{Ni}$ composite electrode. Thus, the $90 \% \mathrm{Pd}-10 \% \mathrm{Ni}$ electrode is the best electrocatalyst among binary composites of $\mathrm{Pd}$ and $\mathrm{Ni}$ of the present investigation. Based on values of the observed oxidation current of forward scan at $\mathrm{E}=-0.20 \mathrm{~V}$, the rates of oxidation of different alcohols on $90 \% \mathrm{Pd}-10 \% \mathrm{Ni}$ followed the order: ethanol $(\mathrm{I}=$ $252 \mathrm{~mA} \mathrm{mg}^{-1}$ catalyst $)>$ methanol $\left(\mathrm{I}=121 \mathrm{~mA} \mathrm{mg}^{-1}\right.$ catalyst $)>$ ethylene glycol $\left(\mathrm{I}=101 \mathrm{~mA} \mathrm{mg}^{-1}\right.$ catalyst $)$ $>$ glycerol $\left(\mathrm{I}=93 \mathrm{~mA} \mathrm{mg}^{-1}\right.$ catalyst $)$.

The increase in electrocatalytic activity of $\mathrm{Pd}$ with $\mathrm{Ni}$ introduction can be ascribed to the higher ionic potential of $\mathrm{Ni}^{2+}$ which can reduce the electron density on $\mathrm{Pd}$. As a result, the Pd-CO bonding energy is decreased and hence the oxidation of CO-like intermediates is enhanced. The $\mathrm{CO}$ molecule is a surface poisoning intermediate in alcohol oxidation. However, $\mathrm{Ni}$ is not a good electrode material because of surface passivation by $\mathrm{NiO}$ [37] and therefore, the 
Table 1. Results of the Cyclic Voltammetry Study of (100-x)\%Pd-x\% Ni Composites in 1M KOH + 1M Alcohol; Scan Rate = 50 $\mathrm{mVs}^{-1}, \mathrm{Temp}=25^{\circ} \mathrm{C}$

\begin{tabular}{|c|c|c|c|c|c|c|c|c|}
\hline \multirow{2}{*}{ Electrode (x \%) } & \multicolumn{2}{|c|}{ Methanol } & \multicolumn{2}{|c|}{ Ethanol } & \multicolumn{2}{|c|}{ Glycerol } & \multicolumn{2}{|c|}{ Ethylene Glycol } \\
\hline & $\begin{array}{c}\mathbf{I}_{\mathrm{p}} / \mathrm{mAmg}^{-1} \\
\text { Catalyst }\end{array}$ & $\mathbf{E}_{\mathbf{p}} / \mathbf{m V}$ & $\begin{array}{c}\mathbf{I}_{\mathrm{p}} / \mathrm{mAmg}^{-1} \\
\text { Catalyst }\end{array}$ & $\mathbf{E}_{\mathrm{p}} / \mathbf{m V}$ & $\begin{array}{c}\mathrm{I}_{\mathrm{p}} / \mathrm{mA} \mathrm{mg}^{-1} \\
\text { Catalyst }\end{array}$ & $\mathbf{E}_{\mathbf{p}} / \mathbf{m V}$ & $\begin{array}{c}\mathbf{I}_{\mathrm{p}} / \mathrm{mAmg}^{-1} \\
\text { Catalyst }\end{array}$ & $\mathbf{E}_{\mathbf{p}} / \mathbf{m V}$ \\
\hline 0 & 83 & -81 & 130 & -138 & 144 & -7 & 73 & -108 \\
\hline 1 & 31 & -90 & 77 & -83 & 43 & -43 & 67 & -58 \\
\hline 2 & 195 & 10 & 281 & 14 & 180 & 41 & 139 & -10 \\
\hline 5 & 199 & -2 & 305 & 28 & 218 & 71 & 158 & -25 \\
\hline 10 & 272 & -12 & 340 & -13 & 235 & 51 & 182 & -35 \\
\hline 20 & 96 & -60 & 150 & -69 & 105 & -9 & 107 & -50 \\
\hline
\end{tabular}

presence of higher content of $\mathrm{Ni}$ in the composite is expected to show an adverse effect [5].

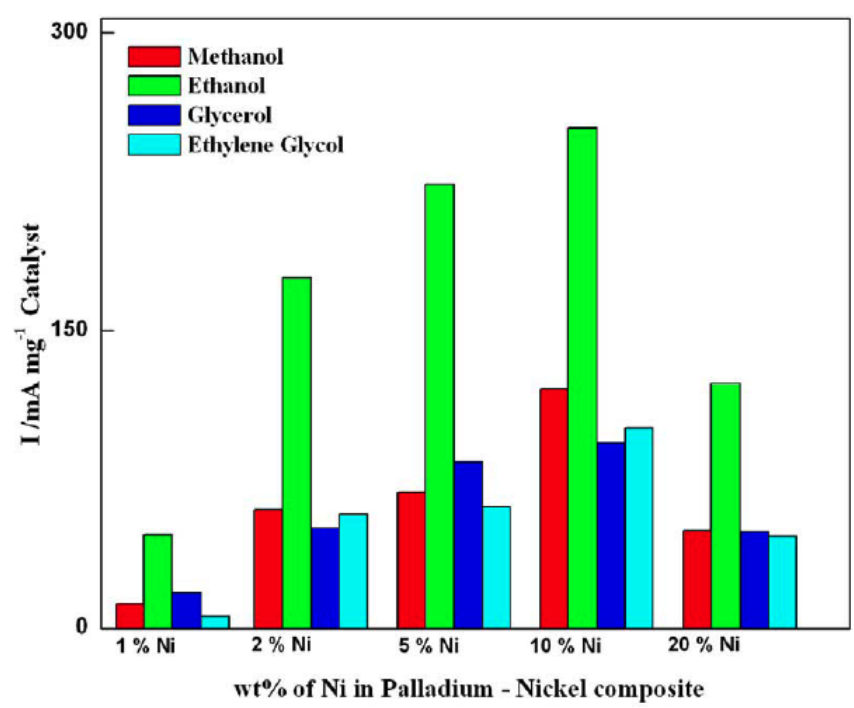

Fig. (5). Bar diagram for electrocatalytic activities of (100-x)\%Pd$\mathrm{x} \% \mathrm{Ni}(\mathrm{x}=1,2,5,10$ and 20$)$ electrodes in $1 \mathrm{M} \mathrm{KOH}+1 \mathrm{M}$ alcohol (methanol, ethanol, glycerol, ethylene glycol) at scan rate of $50 \mathrm{mV} \mathrm{s}^{-1}$ and at $-0.20 \mathrm{~V}$.

\subsubsection{Oxidation of Alcohols (Methanol, Ethanol, Glycerol, Ethylene Glycol) on Ternary Composites of Pd, Ni and C}

To improve the electrocatalytic activity further, 0.5 to $10 \%$ nanocarbon powders were introduced into the active $90 \% \mathrm{Pd}-10 \% \mathrm{Ni}$ composite. Cyclic volammograms of ternary composites, so derived, were recorded in $1 \mathrm{M} \mathrm{KOH}$ and $1 \mathrm{M}$ $\mathrm{KOH}+1 \mathrm{M}$ alcohol at $25^{\circ} \mathrm{C}$. It has been observed that with the exception of $80 \% \mathrm{Pd}-10 \% \mathrm{Ni}-10 \% \mathrm{C}, \mathrm{CVs}$ of all the ternary composite electrodes in blank solution (1 M KOH) were more or less similar to those obtained for $\mathrm{Pd}-\mathrm{Ni}$ composites; only two representative $\mathrm{CV}$ curves, one for $85 \% \mathrm{Pd}-10 \% \mathrm{Ni}-5 \% \mathrm{C}$ and the other one for $80 \% \mathrm{Pd}-10 \% \mathrm{Ni}-$ $10 \% \mathrm{C}$ are shown in Fig. (3). This figure shows that cyclic voltammogram for the $80 \% \mathrm{Pd}-10 \% \mathrm{Ni}-10 \% \mathrm{C}$ electrode exhibits an anodic $\left(\mathrm{E}_{\mathrm{p}}=0.49 \mathrm{~V}\right)$ and a corresponding cathodic $\left(\mathrm{E}_{\mathrm{p}}=0.32 \mathrm{~V}\right)$ peaks for the formation of the $\mathrm{Ni}$ (III) / Ni (II) redox couple [38], while the similar redox peaks are found to be absent on voltammograms for other composite electrodes prepared in the study. Further, the cathodic peak observed at $\mathrm{E}=-0.31 \mathrm{~V}$ for the reduction of $\mathrm{Pd}(\mathrm{II})$ oxide, formed due to the surface oxidation of $\mathrm{Pd}$ under anodic condition, appears to slightly shift towards the noble side in presence of $\mathrm{C}$. The XRD pattern of the $80 \% \mathrm{Pd}-10 \% \mathrm{Ni}-$ $10 \% \mathrm{C}$ composite was also different from other ternary composite catalysts (Fig. 1). So, C addition to pure $\mathrm{Pd}$ was limited to $10 \%$ only.

Fig. (6a-d) gathers CVs of the ternary composite electrodes at $50 \mathrm{mV} \mathrm{s}^{-1}$ in $1 \mathrm{M} \mathrm{KOH}+1 \mathrm{M}$ alcohol. It is observed from Fig. (6) and Table 2 that $\mathrm{C}$ substitution from 0.5 to $10 \%$ enhances the catalytic activity of the base electrode, $90 \% \mathrm{Pd}-10 \% \mathrm{Ni}$, towards the oxidation of alcohols but, they do not follow a definite trend. However, the glycerol electrooxidation reaction at the $80 \% \mathrm{Pd}-10 \% \mathrm{Ni}$ $10 \% \mathrm{C}$ electrode is an exception to it as the observed $\mathrm{I}_{\mathrm{p}}$ value is found considerably low compared to one obtained for the base electrode $(90 \% \mathrm{Pd}-10 \% \mathrm{Ni})$. Based on the peak current values (Table 2), the rates of oxidation of all the alcohols seem to be the highest at the $89 \% \mathrm{Pd}-10 \%$ Ni-1\% C electrode.

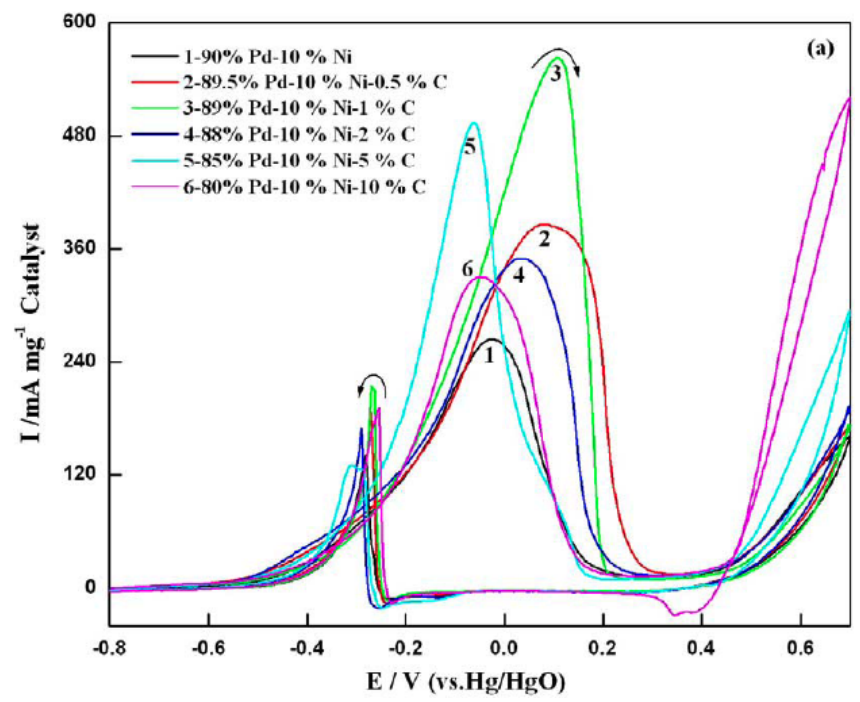

Fig. (6a). Voltammograms for $(90-y) \% \mathrm{Pd}-10 \% \mathrm{Ni}-\mathrm{y} \% \mathrm{C}(\mathrm{y}=0,0.5$, $1,2,5$ and 10) electrodes in $1 \mathrm{M} \mathrm{KOH}+1 \mathrm{MCH}_{3} \mathrm{OH}$ at scan rate of $50 \mathrm{mV} \mathrm{s}^{-1}$.

As the peak potential varies with the nature of the electrocatalyst, the electrocatalytic activities of novel ternary 


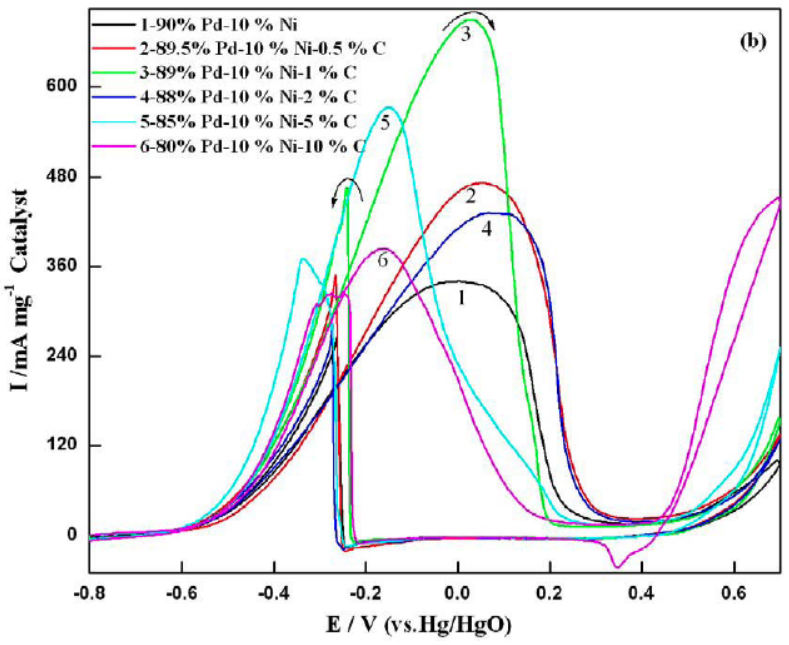

Fig. (6b). Voltammograms for (90-y)\%Pd-10\% Ni-y\% C (y = 0, $0.5,1,2,5$ and 10) electrodes in $1 \mathrm{M} \mathrm{KOH}+1 \mathrm{MC}_{2} \mathrm{H}_{5} \mathrm{OH}$ at scan rate of $50 \mathrm{mV} \mathrm{s}^{-1}$.

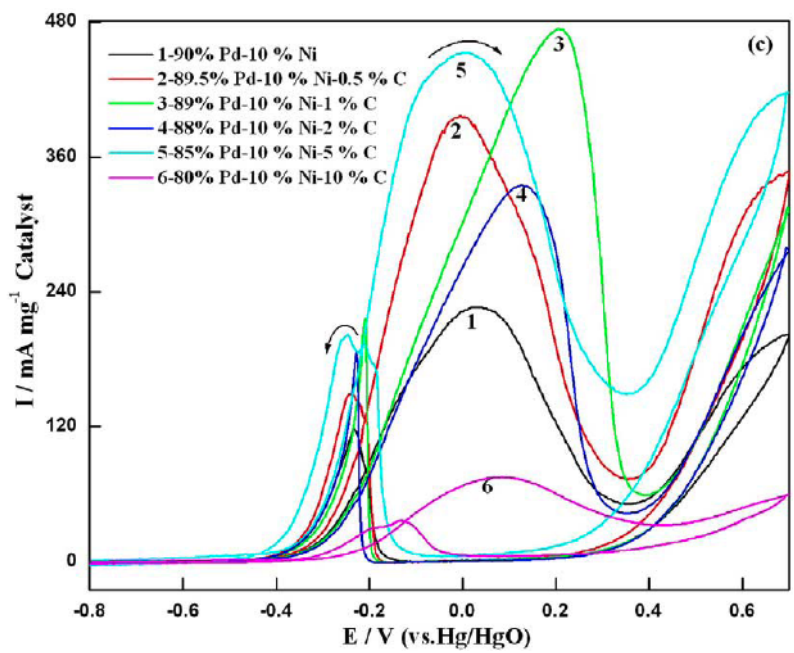

Fig. (6c). Voltammograms for $(90-y) \% \mathrm{Pd}-10 \% \mathrm{Ni}-\mathrm{y} \% \mathrm{C}(\mathrm{y}=0$, $0.5,1,2,5$ and 10) electrodes in $1 \mathrm{M} \mathrm{KOH}+1 \mathrm{M}$ glycerol at scan rate of $50 \mathrm{mV} \mathrm{s}^{-1}$.

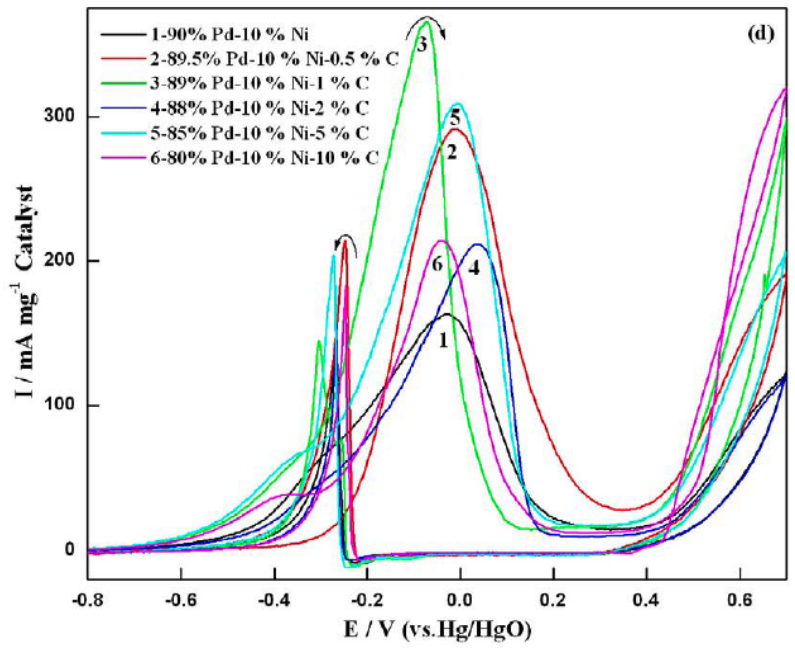

Fig. (6d). Voltammograms for $(90-y) \% P d-10 \% \mathrm{Ni}-\mathrm{y} \% \mathrm{C}(\mathrm{y}=0$, $0.5,1,2,5$ and 10 ) electrodes in $1 \mathrm{M} \mathrm{KOH}+1 \mathrm{M}$ ethylene glycol at scan rate of $50 \mathrm{mV} \mathrm{s}^{-1}$. composite electrodes, prepared by us, for the electrooxidation of each, methanol, ethanol, glycerol, and ethylene glycol in $1 \mathrm{M} \mathrm{KOH}$ at $25^{\circ} \mathrm{C}$ have been compared by measuring the current $(\mathrm{mA} / \mathrm{mg}$ catalyst) produced as a result of oxidation of a particular alcohol on each electrode surface at a constant potential ( $\mathrm{E}=-0.20 \mathrm{~V})$ (Fig. 6) and, data so obtained, are displayed in Fig. (7). This figure demonstrates that among the ternary composite electrodes investigated, the electrode, $85 \% \mathrm{Pd}-10 \% \mathrm{Ni}-5 \% \mathrm{C}$, has the greatest catalytic activity for electrooxidation of methanol, ethanol, glycerol, and ethylene glycol. Based on the rates of oxidation of alcohols on $85 \% \mathrm{Pd}-10 \% \mathrm{Ni}-5 \% \mathrm{C}$ at $\mathrm{E}=-0.20 \mathrm{~V}$, different alcohols followed the activity order: ethanol $(\mathrm{I}=525 \mathrm{~mA}$ $\mathrm{mg}^{-1}$ catalyst $)>$ methanol $\left(\mathrm{I}=198 \mathrm{~mA} \mathrm{mg}^{-1}\right.$ catalyst $)>$ glycerol $\left(\mathrm{I}=192 \mathrm{~mA} \mathrm{mg}^{-1}\right.$ catalyst $)>$ ethylene glycol $(\mathrm{I}=$ $129 \mathrm{~mA} \mathrm{mg}^{-1}$ catalyst ). The observed higher rates of ethanol oxidation on the Pd-based electrocatalysts may be ascribed to the fact that ethanol is selectively oxidized to acetic acid, which is soon transformed into acetate ion in the alkaline environment of the reaction. On the other hand, other alcohols, methanol and glycerol, produces carbonate via $\mathrm{CO}$ intermediate [13, 39]. The $\mathrm{CO}$ is known as a highly poisonous intermediate in the alcohol oxidation reaction. The electrode, $89 \% \mathrm{Pd}-10 \% \mathrm{Ni}-1 \% \mathrm{C}(\mathrm{E}=-0.20 \mathrm{~V}, \mathrm{I}=415 \mathrm{~mA} / \mathrm{mg}$ catalyst), which exhibited the best activity based on the peak current values, is found to be approximately 1.3 times lesser active than the $85 \% \mathrm{Pd}-10 \% \mathrm{Ni}-5 \% \mathrm{C}$ electrode $(\mathrm{E}=-0.20 \mathrm{~V}$, I $=525 \mathrm{~mA} / \mathrm{mg}$ catalyst) under constant potential consideration. It is noteworthy that under similar experimental conditions, the electrocatalytic performance of the electrode $89 \% \mathrm{Pd}-10 \% \mathrm{Ni}-1 \% \mathrm{C}$ (methanol: $\mathrm{I}_{\mathrm{p}} \approx 625 \mathrm{~mA}$ $\mathrm{mg}^{-1}$ of $\mathrm{Pd}, \mathrm{E}_{\mathrm{p}} \approx 0 \mathrm{~V}$ and ethanol: $\approx 783 \mathrm{~mA} \mathrm{mg}^{-1}$ of $\mathrm{Pd}, \mathrm{E}_{\mathrm{p}} \approx 0$ $\mathrm{V}$ ) and $85 \% \mathrm{Pd}-10 \% \mathrm{Ni}-5 \% \mathrm{C}$ (methanol: $\mathrm{I}_{\mathrm{p}} \approx 579 \mathrm{~mA} \mathrm{mg} \mathrm{mof}^{-1}$ $\mathrm{Pd}, \mathrm{E}_{\mathrm{p}} \approx \sim 0 \mathrm{~V}$ and ethanol: $\approx 695 \mathrm{~mA} \mathrm{mg}^{-1}$ of $\mathrm{Pd}, \mathrm{E}_{\mathrm{p}} \approx-0.1$ $\mathrm{V})$ of the present investigation are much higher than those of Pd-Ni/C (methanol: $\mathrm{I}_{\mathrm{p}} \approx 500 \mathrm{~mA} \mathrm{mg}{ }^{-1}$ of $\mathrm{Pd}, \mathrm{E}_{\mathrm{p}} \approx 0 \mathrm{~V}$ ) [34] and $\mathrm{Pd}-\mathrm{NiO}(4: 1) / \mathrm{C}$ (methanol: $\mathrm{I}_{\mathrm{p}} \approx 247 \mathrm{~mA} \mathrm{mg}^{-1}$ of $\mathrm{Pd}, \mathrm{E}_{\mathrm{p}} \approx-$ $0.07 \mathrm{~V}$ and $\mathrm{Pd}-\mathrm{NiO}(6: 1) / \mathrm{C}$ (ethanol: $\approx 317 \mathrm{~mA} \mathrm{mg}^{-1}$ of $\mathrm{Pd}, \mathrm{E}_{\mathrm{p}}$ $\approx-0.08 \mathrm{~V}), \mathrm{Pd}-\mathrm{Co}_{3} \mathrm{O}_{4}(2: 1) / \mathrm{C}$ (methanol: $\mathrm{I}_{\mathrm{p}} \approx 217 \mathrm{~mA} \mathrm{mg}^{-1}$ of $\mathrm{Pd}, \mathrm{E}_{\mathrm{p}} \approx-0.14 \mathrm{~V}$ and $\mathrm{Pd}-\mathrm{Co}_{3} \mathrm{O}_{4}(4: 1) / \mathrm{C}$ (ethanol: $\approx 157 \mathrm{~mA}$ $\mathrm{mg}^{-1}$ of $\mathrm{Pd}, \mathrm{E}_{\mathrm{p}} \approx-0.14 \mathrm{~V}$ ) and $\mathrm{Pd}-\mathrm{Mn}_{3} \mathrm{O}_{4}(2: 1) / \mathrm{C}$ (methanol: $\mathrm{I}_{\mathrm{p}}$ $\approx 153 \mathrm{~mA} \mathrm{mg}{ }^{-1}$ of $\mathrm{Pd}, \mathrm{E}_{\mathrm{p}} \approx-0.09 \mathrm{~V}$ and $\mathrm{Pd}-\mathrm{Mn}_{3} \mathrm{O}_{4}(4: 1) / \mathrm{C}$ (ethanol: $\approx 190 \mathrm{~mA} \mathrm{mg}^{-1}$ of $\mathrm{Pd}, \mathrm{E}_{\mathrm{p}} \approx-0.08 \mathrm{~V}$ ) [7] electrodes reported in the literature. However, Bambagioni et al. [13] and Bianchini et al. [21] reported much higher activities on Pd-MWCNT (methanol: $I_{p} \approx 1100 \mathrm{~mA} \mathrm{mg}^{-1}$ of $\mathrm{Pd} E_{p} \approx-0.15$ $\mathrm{V}$ vs $\mathrm{Ag} / \mathrm{AgCl} / \mathrm{KCl}_{\text {sat }}$ and ethanol: $I_{p} \approx 2100 \mathrm{~mA} \mathrm{mg}^{-1}$ of $\mathrm{Pd}$, $E_{p} \approx-0.12 \mathrm{~V}$ vs $\mathrm{Ag} / \mathrm{AgCl} / \mathrm{KCl}_{\text {sat }}$ ) and $\mathrm{Pd}-\mathrm{Ni}-\mathrm{Zn} / \mathrm{C}$ (ethanol: $I_{p}$ $\approx 3600 \mathrm{~mA} \mathrm{mg}{ }^{-1}$ of $\mathrm{Pd}, E_{p} \approx-0.15 \mathrm{~V}$ vs $\mathrm{Ag} / \mathrm{AgCl} / \mathrm{KCl}_{\mathrm{sat}}$ ) electrodes, respectively. Moreover, the electrocatalytic activities of the latter electrodes were tested in much higher concentrations of alcohol (10\%) as well as $\mathrm{KOH}(2 \mathrm{M})$.

\subsection{Chronoamperometry}

The chronoamperometry study of $\mathrm{Pd}$ and composite electrodes $(90 \% \mathrm{Pd}-10 \% \mathrm{Ni}, 80 \% \mathrm{Pd}-20 \% \mathrm{Ni}, 89 \% \mathrm{Pd}-10 \%$ $\mathrm{Ni}-1 \% \mathrm{C}, 85 \% \mathrm{Pd}-10 \% \mathrm{Ni}-5 \% \mathrm{C}$ and $80 \% \mathrm{Pd}-10 \% \mathrm{Ni}-10 \%$ C) has been carried out at $\mathrm{E}=-0.20 \mathrm{~V}$ in $1 \mathrm{M} \mathrm{KOH}+1 \mathrm{M}$ alcohol for $2 \mathrm{~h}$ and results are shown in Fig. (8a, b). This study was made in only two electrolytes, $1 \mathrm{M} \mathrm{KOH}+1 \mathrm{M}$ $\mathrm{CH}_{3} \mathrm{OH}$ and $1 \mathrm{M} \mathrm{KOH}+1 \mathrm{M} \mathrm{C}_{2} \mathrm{H}_{5} \mathrm{OH}$. Fig. (8) demonstrates that the $85 \% \mathrm{Pd}-10 \% \mathrm{Ni}-5 \% \mathrm{C}$ composite electrode 
Table 2. Results of the Cyclic Voltammetry Study of $(90-y) \% P d-10 \%$ Ni-y $\%$ C composites in $1 \mathrm{M}$ KOH $+1 \mathrm{M}$ Alcohol; Scan Rate = $50 \mathrm{mVs}^{-1}, \mathrm{Temp}=\mathbf{2 5}^{\circ} \mathrm{C}$

\begin{tabular}{|c|c|c|c|c|c|c|c|c|}
\hline \multirow{2}{*}{ Electrode (y \%) } & \multicolumn{2}{|c|}{ Methanol } & \multicolumn{2}{|c|}{ Ethanol } & \multicolumn{2}{|c|}{ Glycerol } & \multicolumn{2}{|c|}{ Ethylene Glycol } \\
\hline & $\begin{array}{c}\mathbf{I}_{\mathrm{p}} / \mathrm{mAmg}^{-1} \\
\text { Catalyst }\end{array}$ & $\mathbf{E}_{\mathrm{p}} / \mathbf{m V}$ & $\begin{array}{c}\mathbf{I}_{\mathrm{p}} / \mathrm{mAmg}^{-1} \\
\text { Catalyst }\end{array}$ & $\mathbf{E}_{\mathrm{p}} / \mathbf{m V}$ & $\begin{array}{c}\mathbf{I}_{\mathrm{p}} / \mathrm{mA} \mathrm{mg}^{-1} \\
\text { Catalyst }\end{array}$ & $\mathbf{E}_{\mathrm{p}} / \mathbf{m V}$ & $\begin{array}{c}\mathbf{I}_{\mathrm{p}} / \mathrm{mAmg}^{-1} \\
\text { Catalyst }\end{array}$ & $\mathbf{E}_{\mathbf{p}} / \mathbf{m V}$ \\
\hline 0 & 272 & -12 & 340 & -13 & 235 & 51 & 182 & -35 \\
\hline 0.5 & 391 & 69 & 499 & 37 & 398 & -13 & 279 & -9 \\
\hline 1 & 560 & 98 & 701 & 30 & 481 & 207 & 337 & -62 \\
\hline 2 & 371 & 39 & 450 & 71 & 315 & 135 & 215 & 24 \\
\hline 5 & 490 & -56 & 588 & -134 & 470 & 5 & 300 & -5 \\
\hline 10 & 324 & -41 & 399 & -150 & 81 & 55 & 227 & -52 \\
\hline
\end{tabular}

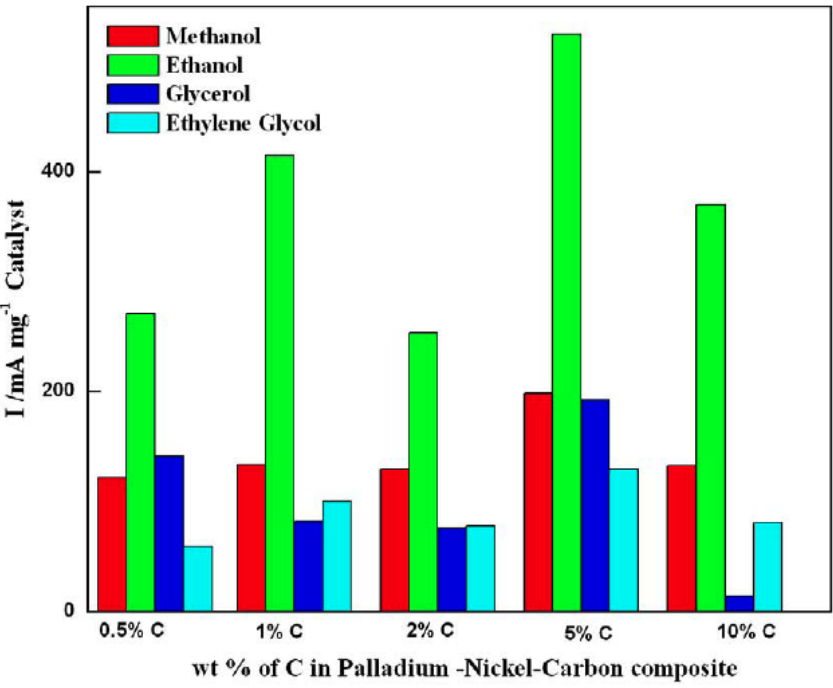

Fig. (7). Bar diagram for electrocatalytic activities of $(90-\mathrm{y}) \% \mathrm{Pd}-$ $10 \% \mathrm{Ni}-\mathrm{y} \% \mathrm{C}(\mathrm{y}=0.5,1,2,5$ and 10$)$ electrodes in $1 \mathrm{M} \mathrm{KOH}+1$ $\mathrm{M}$ alcohol (methanol, ethanol, glycerol, ethylene glycol) at scan rate of $50 \mathrm{mV} \mathrm{s}^{-1}$ and at $-0.20 \mathrm{~V}$.

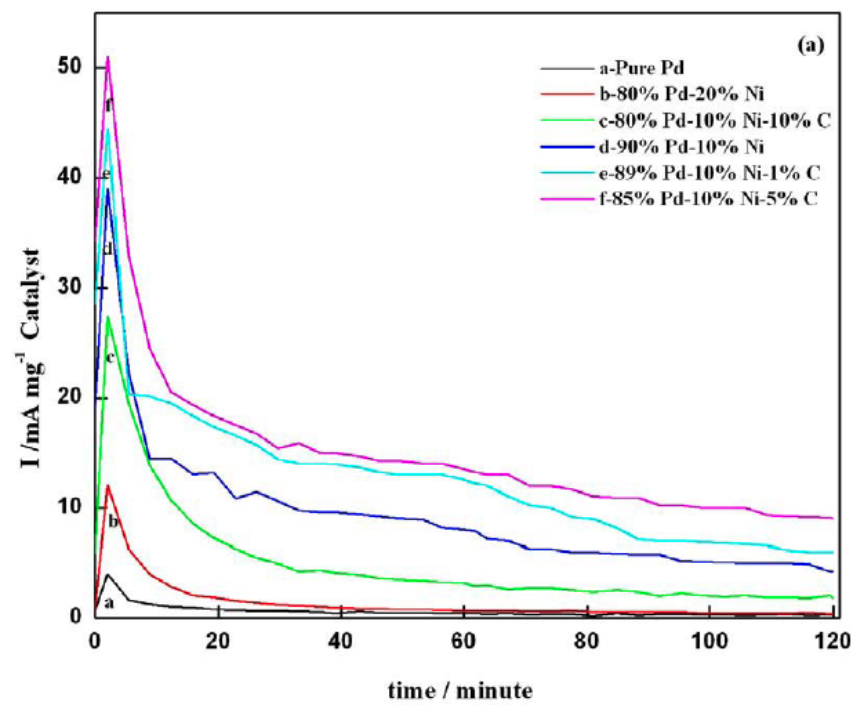

Fig. (8a). Chronoamperograms of pure Pd and composite electrodes (90\%Pd-10\% Ni, 80\%Pd-10\%Ni-10\%C), 89\%Pd-10\% Ni-1\% C, $85 \% \mathrm{Pd}-10 \% \mathrm{Ni}-5 \% \mathrm{C}$ and $80 \% \mathrm{Pd}-10 \% \mathrm{Ni}-10 \% \mathrm{C}$ ) at $\mathrm{E}=-0.20 \mathrm{~V}$ in $1 \mathrm{M} \mathrm{KOH}+1 \mathrm{M}$ methanol.

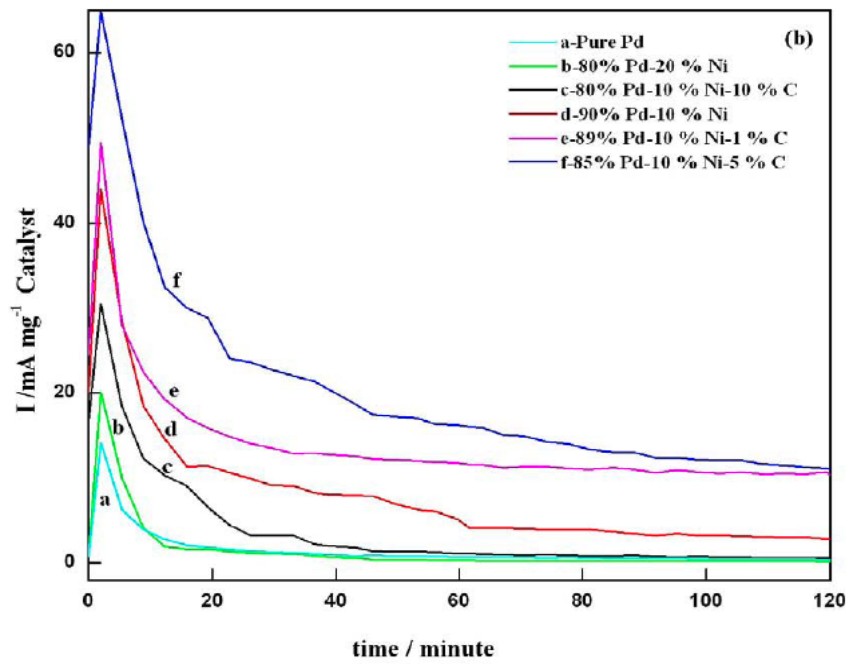

Fig. (8b). Chronoamperograms of pure $\mathrm{Pd}$ and composite electrodes $90 \% \mathrm{Pd}-10 \% \mathrm{Ni}, 80 \% \mathrm{Pd}-10 \% \mathrm{Ni}-10 \% \mathrm{C}, 89 \% \mathrm{Pd}-10 \%$ $\mathrm{Ni}-1 \% \mathrm{C}, 85 \% \mathrm{Pd}-10 \% \mathrm{Ni}-5 \% \mathrm{C}$ and $80 \% \mathrm{Pd}-10 \% \mathrm{Ni}-10 \% \mathrm{C}$ ) at $\mathrm{E}=-$ $0.20 \mathrm{~V}$ in $1 \mathrm{M} \mathrm{KOH}+1 \mathrm{M}$ ethanol.

electrode has considerably improved performance as well as poisoning tolerance compared to pure $\mathrm{Pd}$ and $90 \% \mathrm{Pd}-10 \%$ $\mathrm{Ni}$ and $89 \% \mathrm{Pd}-10 \% \mathrm{Ni}-1 \% \mathrm{C}$ composite electrodes.

\section{CONCLUSIONS}

The study shows that introduction of $\mathrm{Ni}$ from 1 to $20 \%$ into $\mathrm{Pd}$ increases the apparent electrocatalytic activity significantly, the activity being the greatest with $10 \% \mathrm{Ni}$. This is found to be true in case of electrooxidation of all the alcohols chosen for the investigation. The electrocatalytic activity of this (i.e., $90 \% \mathrm{Pd}-10 \% \mathrm{Ni}$ ) electrode towards electrooxidation of alcohols is enhanced further with addition of 0.5 to $10 \% \mathrm{C}$, the activity measured in ' $\mathrm{mA} / \mathrm{mg}$ catalyst' at $\mathrm{E}=-0.20 \mathrm{~V}$ being the greatest with $5 \% \mathrm{C}$. The poisoning tolerance of the latter electrode was also found to be better than other electrodes of the investigation. The rate of ethanol oxidation was the highest on each composite electrode regardless of their nature. Thus, the results appear to be quite useful in the context of development of direct alcohol fuel cells.

\section{ACKNOWLEDGEMENT}

One of authors (R. Awasthi) thanks the Council of Scientific and Industrial Research, Government of India, 
New Delhi for the award of the Junior Research Fellowship (JRF) to carry out the work.

\section{REFERENCES}

[1] Xu, C.; Shen, PK.; Ji, X.; Zeng, R.; Liu, Y. Enhanced activity for ethanol electrooxidation on $\mathrm{Pt}-\mathrm{MgO} / \mathrm{C}$ catalysts. Electrochem. Commun., 2005, 71, 305-71308.

[2] Wei, Z.D.; Li, L.L.; Luo, Y.H.; Yan, C.; Sun, C.X.; Yin, G.Z.; Shen, P.K. Electrooxidation of methanol on upd-Ru and upd-Sn modified Pt Electrodes. J. Phys. Chem. B, 2006, 110, 26055-26061.

[3] Chen, S.; Schell, M. Bistability and excitability in the electrochemical oxidation of ethanol. Electrochim Acta, 1999, 44, 4773-4780.

[4] Chen, S.; Schell, M. A comparison of multistability in the electrocatalyzed oxidation of methanol and ethanol in acid and alkaline solutions. J. Electroanal Chem, 1999, 478, 108-117.

[5] Singh, R.N.; Anindita; Singh, A.; Mishra, D. Composite films of Pd, nanocarbon and $\mathrm{Ni}$ for ethanol oxidation. 1st International Conference on Nanostructured Materials and Nanocomposites. Applied Science Innovations private Limited, India (6 - 8 April 2009, Kottayam, India) 255-267.

[6] Platinum 2008 Interim Review. Platinum Metals Rev. 2009, 53, 48-49.

[7] Xu, C.; Tian, Z.; Shen, P.K.; Jiang, S.P. Oxide $\left(\mathrm{CeO}_{2}, \mathrm{NiO}, \mathrm{Co}_{3} \mathrm{O}_{4}\right.$ and $\mathrm{Mn}_{3} \mathrm{O}_{4}$ )-promoted $\mathrm{Pd} / \mathrm{C}$ electrocatalysts for alcohol electrooxidation in alkaline media. Electrochim Acta, 2008; 53, 2610-2618.

[8] Xu, C.; Shen, P.K.; Liu, Y. Ethanol electrooxidation on Pt/C and Pd/C catalysts promoted with oxide. J. Power Sources, 2007, 164, 527-531.

[9] Hu, F.P.; Chen, C.; Wang, Z.Y.; Wei, G.; Shen, P.K. Mechanistic study of ethanol oxidation on $\mathrm{Pd}-\mathrm{NiO} / \mathrm{C}$ electrocatalyst. Electrochim Acta, 2006, 52, 1087-1091.

[10] Zheng, H.T.; Li, Y.; Chen, S.; Shen, P.K. Effect of support on the activity of Pd electrocatalyst for ethanol oxidation. J. Power Sources, 2006, 163, 371-375.

[11] Xu, C.W.; Cheng, L.; Shen, P.K.; Liu, Y.L. Methanol and ethanol electrooxidation on Pt and Pd supported on carbon microspheres in alkaline media. Electrochem. Commun, 2007, 9, 997-1001.

[12] Hu, F.P.; Wang, Z.Y.; Li, Y.L.; Liu, C.M.; Zhang, X.; Shen, P.K. Improved performance of Pd electrocatalyst supported on ultrahigh surface area hollow carbon spheres for direct alcohol fuel cells. $J$. Power Sources, 2008, 177, 61-66.

[13] Bambagioni, V.; Bianchini, C.; Marchionni, A.; Filippi, J.; Vizza, F.; Teddy, J.; Serp, P.; Zhiani, M. Pd and Pt-Ru anode electrocatalysts supported on multi-walled carbonnanotubes and their use in passive and active direct alcohol fuel cells with ananion-exchange membrane (alcohol =methanol, ethanol, glycerol). J. Power Sources, 2009, 190, 241-251.

[14] Shen, P.K.; Xu, C. Alcohol oxidation on nanocrystalline oxide Pd/C promoted electrocatalysts. Electrochem. Commun., 2006, 8, 184-188.

[15] Chu, D.; Wang, J.; Wang, S.; Zha, L.; He, J.; Hou, Y.; Yan, Y.; Lin, H.; Tian, Z. High activity of $\mathrm{Pd}-\mathrm{In}_{2} \mathrm{O}_{3} / \mathrm{CNTs}$ electrocatalyst for electrooxidation of ethanol. Catal. Commun., 2008, 10, 955-958.

[16] Xu, C.W.; Wang, H.; Shen, P.K.; Jiang, S.P. Highly ordered Pd nanowire arrays as effective electrocatalysts for ethanol oxidation in direct alcohol fuel cells. Adv. Mater., 2007, 19, 4256-4259.

[17] Cheng, F.L.; Wang, H.; Sun, Z.H.; Ning, M.X.; Cai, Z.Q.; Zhang, M. Electrodeposited fabrication of highly ordered Pd nanowire arrays for alcohol electrooxidation. Electrochem. Commun, 2008, 10, 798-801.

[18] Zhang, K.F.; Guo, D.J.; Liu, X.; Li, J.; Li, H.L.; Su, Z.X. Vanadium oxide nanotubes as the support of Pd catalysts for methanol oxidation in alkaline solution. J. Power Sources, 2006, 162, 1077-1081.

[19] Xu, M.W.; Gao, G.Y.; Zhou, W.J.; Zhang, K.F.; Li, H.L. Novel Pd/B$\mathrm{MnO}_{2}$ nanotubes composites as catalysts for methanol oxidation in alkaline solution. J. Power Sources, 2008, 175, 217-220.

[20] Bagchi, J.; Bhattacharya, S.K. Electrocatalytic activity of binary Palladium Ruthenium anode catalyst on Ni-support for ethanol alkaline fuel cells. Trans. Met. Chem, 2007, 32, 47-55.
[21] Bambagioni, V.; Bianchini, C.; Filippi, J.; Oberhauser, W.; Marchionni, A.; Vizza, F.; Psaro, R.; Sordelli, L.; Foresti, M.L.; Innocenti, M. Ethanol oxidation on electrocatalysts obtained by spontaneous deposition of palladium onto nickel-zinc materials. Chem Sus Chem, 2009, 2, 99-112.

[22] Demarconnay, L.; Brimaud, S. ; Coutenceau, C. ; Leger, J.M. Ethylene glycol electrooxidation in alkaline medium at multi-metallic Pt based catalysts. J. Electroanal. Chem., 2007, 601, 169-180.

[23] Zheng, H.T.; Chen, S.X.; Shen, P.K. Spontaneous formation of platinum particles on electrodeposited palladium. Electrochem. Commun., 2007, 9, 1563-1566.

[24] Wang, H.; Xu, C.; Cheng, F.; Zhang, M.; Wang, S.; Jiang, S.P. Pd/Pt core-shell nanowire arrays as highly effective electrocatalysts for methanol electrooxidation in direct methanol fuel cells. Electrochem. Commun., 2008, 10, 1575-1578.

[25] Nie, M.; Tang, H.L.; Wei, Z.D.; Jiang, S.P.; Shen, P.K. Highly efficient AuPd-WC/C electrocatalyst for ethanol oxidation. Electrochem. Commun., 2007, 9, 2375-2379.

[26] Zhang, J.; Huang, M.; Ma, H.; Tian, F.; Pan, W.; Chen, S. High catalytic activity of nanostructured Pd thin films electrochemically deposited on polycrystalline Pt and Au substrates towards electrooxidation of methanol. Electrochem. Commun., 2007, 9, 1298-1304.

[27] Xu, C.W.; Tian, Z.Q.; Chen, Z.C.; Jiang, S.P. Pd/C promoted by Au for 2-propanol electrooxidation in alkaline media. Electrochem. Commun. 2008, 10, 246-249.

[28] Singh, R.N.; Anindita; Singh, A. Electrocatalytic activity of binary and ternary composite films of Pd, MWCNT and Ni for ethanol electrooxidation in alkaline solutions. Carbon, 2009, 47, 271-278.

[29] Kumar, K.S.; Haridoss, P.; Seshadri, S.K. Synthesis and characterization of electrodeposited $\mathrm{Ni}-\mathrm{Pd}$ alloy electrodes for methanol oxidation. Surf. Coat. Technol., 2008, 202, 1764-1770.

[30] Singh, R.N.; Singh, A.; Anindita. Electrocatalytic activity of binary and ternary composite films of Pd, nanocarbon and $\mathrm{Ni}$ for electro-oxidation of methanol in alkaline medium. J. Solid State Electrochem., 2009, 13, 1259-1265.

[31] Singh, R.N.; Singh, A.; Anindita. Electrocatalytic activity of binary and ternary composite films of Pd, MWCNT and Ni, Part II: Methanol electrooxidation in $1 \mathrm{M} \mathrm{KOH}$. Int. J. Hydrogen Energy, 2009, 34, 20522057.

[32] Wang, J.; Xi, J.; Bai, Y.; Shen, Y.; Sun, J.; Chen, L.; Zhu, W.; Qiu, X. Structural designing of $\mathrm{Pt}-\mathrm{CeO}_{2} / \mathrm{CNTs}$ for methanol electro-oxidation. J. Power Sources., 2007, 164, 555-560.

[33] Singh, R.N.; Sharma, T.; Singh, A.; Anindita; Mishra, D.; Tiwari, S.K. Perovskite-type $\mathrm{La}_{2-\mathrm{x}} \mathrm{Sr}_{\mathrm{x}} \mathrm{NiO}_{4}(0 \leq \mathrm{x} \leq 1)$ as active anode materials for methanol oxidation in alkaline solutions. Electrochim. Acta, 2008, 53, 2322-2330.

[34] Liu, Z.; Zhang, X.; Hong, L. Physical and electrochemical characterization of nanostructred $\mathrm{Pd} / \mathrm{C}$ and $\mathrm{PdNi} / \mathrm{C}$ catalysts for methanol oxidation. Electrochem. Commun., 2009, 11, 925-928.

[35] Liu, J.; Ye, J.; Xu, C.; Jiang, S.P.; Tong, Y. Kinetics of ethanol electrooxidation at Pd electrodeposited on Ti. Electrochem. Commun., 2007, 9, 2334-2339.

[36] Huang, J.C.; Liu, Z.L.; He, C.B.; Gan, L.M. Synthesis of PtRu nanoparticles from the hydrosilylation reaction and application as catalyst for direct methanol fuel cell. J. Phys. Chem. B, 2005, 109, 16644-16649.

[37] Shobha, T.; Aravinda, CL.; Bera, P.; Devi, L.G.; Mayanna, S.M. Characterization of Ni-Pd alloy as anode for methanol oxidative fuel cell. Mat. Chem. Phys., 2003, 80, 656-661.

[38] Tiwari, S.K.; Samuel, S.; Singh, R.N.; Poillerat, G.; Koenig, J.F.; Chartier, P. Active thin $\mathrm{NiCO}_{2} \mathrm{O}_{4}$ film prepared on nickel by spray pyrolysis for oxygen evolution. Int. J. Hydrogen Energy, 1995, 20, 915.

[39] Bianchini, C.; Shen, P.K. Palladium-based electrocatalysts for alcohol oxidation in half cells and in direct alcohol fuel cells. Chem. Rev., 2009, $109,4183-4206$. 